\title{
ПОСТМОДЕРН В НАУКЕ И РЕЛИГИИ
}

\section{Т.Н. Поплавская}

Как известно, становление постмодернизма связано с рефлексией не столько над наукой и религией, сколько над искусством и литературой. Однако, обнаруженные «болевые точки» современной культуры в определенной мере имеют отношение и к науке, и к религии.

Анализируя ситуацию, сложившуюся в современной науке, некоторые исследователи приходят к неутешительным выводам, которые можно выразить при помощи следующего вопроса: «Действительно ли изменения в науке настолько радикальны, что о ней не приходится больше говорить, можем ли сделать вывод о том, что науке пришел конец?» Пытаясь найти ответ на этот вопрос, вспомним, для начала, мнение на этот счет одного из величайших физиков XX века В. Гейзенберга, который писал, что квантовая механика выдвинула настолько серьезные требования, что «пришлось вообще отказаться от объективного - в ньютоновском смысле- описания природы» [2, с. 192]. Или, в другом месте: «Если в наше время можно говорить о картине природы, складывающейся в точных науках, речь, по сути дела, идет уже не о картине природы, а о картине наших отношений к природе. Старое разделение мира на объективный ход событий в пространстве и времени, с одной стороны, и душу, в которой отражаются эти события, - с другой, иначе говоря, картезианское различение res cogitans и res extensa уже не может служить отправной точкой в понимании современной науки» [2, с. 303]. Как видим, Гейзенберг выводит за пределы основания квантовой механики тезис о противостоянии субъекта и объекта и, исходя из этого, считает неизбежным отказ от объективного описания природы, по крайней мере, в ньютоновском смысле.

Развитие философии и истории науки в XX веке явно тяготело к признанию все большего значения субъектного полюса в познавательной деятельности. Начиная с Т. Куна, даже уже с А. Койре, научное знание все 
глубже погружается в контекст истории, культуры, научного сообщества как социального образования. История и философия науки по своей проблематике постепенно совмещаются с социологией, общие для этих трех дисциплин проблемы решаются социологическими средствами. В связи с этим появляется угроза релятивизации научного знания, его содержание теперь определяется не природой, как неизменным предметом изучения, а исторически меняющимся социальным контекстом.

В философии науки, которая явно социологизируется, доминирующими - после Куна - становятся представления о сосуществовании в истории разных парадигм, каждая из которых не утрачивает своего исторического и логического значения после возникновения новой. С появлением фундаментальной парадигмы изменяется не только объяснение мира, но и самый мир. Соответствие теории природе сохраняется, но объективность здесь уже не ньютоновского типа, как писал Гейзенберг. Каждой крупной теории присущ и свой мир. Принцип соответствия или принцип дополнительности в физике утверждают сосуществование разных теорий и соответствующих им миров. Меняется представление о субъекте: он, в значительной степени, «опредмечивается», так как логические отношения между членами научного сообщества оказываются включенными в теоретическую структуру знания, а не остаются полностью за ее пределами. По той же причине изменяется и объект изучения: он в какой-то степени «распредмечивается», приобретает субъектные характеристики. Пересматриваются понятия истины, объективности, логической совместимости, историчности. Одновременно в культуре и философии выдвигаются на передний план идеи диалога. Наиболее полное философское и логическое воплощение эти идеи нашли, на наш взгляд, в диалогике, или культурологии, В.С. Библера [1].

Показательна в данном контексте позиция американского социолога K. Кнорр. Она радикально пересматривает соотношение научного знания и природы. По ее мнению, продукты научной деятельности не соответствуют чему-то в природе, скорее, они выкованы, сконструированы, преобразованы из чего придется. Отсюда и соответствующие задачи, которые возникают, по мнению В. Гейзенберга, перед социологами науки: «...Вместо того, чтобы изучать внешние отношения между наукой и «природой», которую, как нам говорят, она описывает, мы рассмотрим те внутренние дела научного предприятия, которые мы считаем конструктивными» $[2$, с.3]. Социологу достаточно изучить положение дел в лаборатории, совокупность всех отношений, сложившихся здесь, чтобы понять научную деятельность как таковую. Достижение успеха, а не получение истины-вот что является главным для ученого. Таким образом, философы, историки и социологи к концу ХХ века создают такой образ науки, в котором от науки вроде ничего и не остается. 
По мнению одного из исследователей постмодерна С. Корнева, «постмодернизм - это полное крушение культурной логики Запада и западной рациональности, в том виде, в каком она сложилась во времена Декарта» [3]. Философы постмодерна (Бодрийар, Делез, Деррида, Лиотар, Фуко, Хайдеггер) занимаются «деконструкцией» двухтысячелетнего философского наследия, доказывая условность и искусственный, «насильственный» характер основных категорий западной рациональности. Исчезла вера в существование каких-то общих принципов и законов, которые управляют этим миром; исчезло доверие к самому человеческому разуму. Еще вчера четкие и очевидные для всех рамки понятий, выработанные столетиями предшествующего развития мысли, превращаются в вязкий туман, который скорее запутывает, чем что-то проясняет. Логические категории теряют свою строгость и начинают «наплывать» друг на друга. Становится непонятно не только где истина, а где ложь, но и сами категории лжи и истины, которыми когда-то гордился здравый человеческий рассудок, теряют свой смысл.

Проблема смысла, истины и лжи обсуждалась на конференции теологов под названием «Роль религии в эпоху постмодерна» [4], материалы которой были опубликованы в 1987 г. В религии присутствуют две характеристики, одинаково для нее существенные, которые, однако, в XX в. начинают выглядеть особенно несовместимыми. С одной стороны, религиозные догматы как некоторые «религиозные истины», полученные через откровение, приобщены к абсолютному Божественному Логосу и не зависят от человеческого рационального мышления, доминирующего в мире земной необходимости. С другой стороны, религия представляет органический элемент культуры, и ее догматы выражаются языком этой культуры. Возникает вопрос: если религиозная истина, воплощенная в догматах, несет на себе печать конкретной культуры, то как быть с ее неземным, трансцендентным содержанием? А если она этой печати не несет, то можно ли ее считать органической составляющей культуры? Две особенности религии, вроде бы в равной степени неотъемлемые от нее, при их соотнесении друг с другом выступают как проблема, как серьезная трудность.

В выступлениях участников конференции, большинство из которых были протестантами, доминировал герменевтический подход, христианская религия, ее место в обществе анализировались через призму Библии как текста. Работа с текстом приводит к разным толкованиям Библии, каждое из которых имеет право на существование. Толкование Библии контекстуально. Библия - это история ее интерпретаций, а не предмет изучения.

До последнего времени религия ничуть не в меньшей, а даже в большей степени, чем наука, характеризовалась нетерпимостью к плюрали- 
зму: слово Бога звучит одинаково в любом месте и в любое время, в Библии заложен определенный смысл, который надо обнаружить, и только одно толкование которого может быть истинным, а все остальные автоматически считаются ложными. Библия несет в себе некоторую абсолютную истину, и никакой контекст не может повлиять на ее содержание. Но тогда почему в христианском мире за две тысячи лет образовалось столько течений и направлений, каждое из которьх толкует Библию по-своему, объявляя остальные ложными, еретическими и т.д.?

В условиях постмодерна, как это видно из докладов на конференции, в акте чтения акцент переносится на человеческий полюс, на множественность толкований, которые вступают друг с другом в определенного типа отношения, в том числе в отношения диалогического характера. Читающий Писание имеет дело, в первую очередь, не с событиями, которые там излагаются, а с разными способами их истолкования, с историей этих толкований, осуществлявшихся в отличающихся друг от друга исторических и социальных контекстах. Содержание текста как предмет предстает в лице своих истолкователей. За этим множеством толкований предмет как нечто устойчивое и самодостаточное теряется. Герменевтическая парадигма диалогического общения заменяет нововременную парадигму субъект-объектных отношений. Если считать предметом теологии, в конечном счете, откровение и постигаемого с его помощью Бога, то Бог вроде как исчезает из Священных текстов. Диалогические отношения лишают его исключительного положения, смена участников диалога, культурных контекстов приводит к изменчивости Бога, а это уже не Бог.

Итак, ситуации в науке и в религии оказываются, в определенном смысле, сходными. В науке исчезает предмет изучения - можно ли говорить в этом случае о науке? В религии исчезает предмет веры, поклонения, воплощенный в Священных текстах - что же остается от религии?

Если обратиться к истории, то можно сказать, что в Средние века доминирующим был тезис о превосходстве Божественного разума и только приобщение к нему делало естественный разум работающим и эффективным. В Новое время человеческий земной разум существовал как бы рядом и параллельно с Божественным. В конце ХХ в. светская философия выступает с претензией на понимание своими средствами трансцендентного мира божественной логики, претендует на «захват» ее территории. Если перефразировать слова Вольтера, то от лица постмодернистской философии можно сказать: даже если Бог и есть, разумнее сделать вид, что его не существует.

Таким образом, ситуация постмодерна в современной западной культуре пришла к своему логическому тупику: в науке познающий субъект, со всеми его культурными, социальными, историческими характеристиками, столь затрудняющими объективную интерпретацию научного знания, 
заменяется свойством вещей воспринимать внешние воздействия друг на друга и в результате этот субъект оказывается полностью выключенным из исторического контекста, из сферы какой бы то ни было человеческой деятельности; в религии же нет Бога, а тем самым отрицается и религия как таковая. Действительно, если читающий Священное писание убежден, что за его строчками нет Бога, а есть только разные интерпретации самого текста, то такой человек не может быть религиозным, религии для него не существует. Таков итог развития западного рационализма во всех областях западной культуры, сущность которой уже не нуждается ни в понятии «сущности» (как чего-то противоположного явлению), ни в понятии «значения» (как чего-то противоположного знаку). Ее Сущность без остатка материализовалась в ее технике, науке, искусстве, в ее социальных институтах, в знаковых системах, на которые они опираются. Некогда живая и неявленная Сущность культуры окостенела в реально существующем, но мертвом, бездушном механизме. «Феномен» теперь отсылает не к «сущности», а к другому феномену, с которым он связан в рамках функционирования этой машины, а «знак» отсылает не к «значению», а к другому знаку, с которым он связан в рамках системы коммуникации, координирующей работу этого муравейника. Смысл из этой системы ушел - остались только чисто механические связи «стимул-реакция», «кнут-пряник». Нет ничего странного в том, что сегодня западная цивилизация даже самим западным людям иногда представляется мертвой, бездушной «Системой», врагом, с которым нужно бороться. «Постмодернизм - это реакция отторжения фундаментальных ценностей Запада со стороны самого же западного человека, который сегодня не узнает себя в своей цивилизации, в своем собственном творении» [3].

Тем не менее, есть авторы, которые утверждают, что «рефлексия над постмодернистской ситуацией указывает не на крах рациональности, а на либерализацию ее критериев, которую (либерализацию), в свою очередь, можно квалифицировать и как постмодернистскую тенденцию в современной науке и/или культуре» [5, с. 85]. Поясняя эту мысль, В.С. Ратников отмечает: «Либерализацию здесь мы трактуем как выход за пределы прежнего (ранее считавшегося каноническим, например, в теоретическом естествознании) требования обязательной эмпирической обоснованности (эмпирической верифицированности) построенной теоретической модели для того, чтобы признать ее, например, физической (если она строится для решения какой-либо задачи теоретической физики) или даже научной» [5, с. 81]. И далее: «Можно говорить о либерализации традиционных критериев рациональности другого типа - об ослаблении позиций детерминизма, и в частности, об ослаблении требования в научных способах описания - отказ от глобальной предсказуемости репрезентируемых феноменов» $[5$, с. 83]. Кроме того, к либерализации критериев рационально- 
сти В.С. Ратников относит и те изменения, которые произошли в понимании соотношения простоты, сложности и предсказуемости. Классическая наука предполагает, что простота и предсказуемость вполне совместимы в рамках механистической картины мира и лапласовского детерминизма. Однако на современном этапе формируется концепция локальной непредсказуемости, вырастающая из опыта применения нелинейных моделей в неравновесной термодинамике, синергетике, современной теории динамических систем и др. [5, с. 85].

Как неопровержимо свидетельствует исторический опыт, догматизм и скептицизм равно неплодотворны ни в науке, ни в религии, а в вопросах об их соотношении - тем более. Такого рода догматический подход исключает возможность всякого диалога и делает невозможным достижение взаимопонимания. Поэтому, не отрицая многообразия точек зрения, следует всё же попытаться найти такое объективное основание их сопоставления, которое бы: а) давало возможность рассмотреть религию и науку как некие относительно устойчивые феномены в межкультурном и историческом планах; б) позволило объяснить закономерности их взаимодействия; в) определить перспективы их развития.

$\mathrm{C}$ этих позиций наука и религия могут быть рассмотрены как самостоятельные и автономные области духовного опыта (и, соответственно, различные сферы духовной культуры), связанные с деятельностью различных познавательных способностей сознания и обеспечивающие в силу этого многомерное и многогранное творческое бытие человека в мире.

\section{1 Литература}

[1] Библер B.C. От наукоучения к логике культуры. - М., 1991.

[2] Гейзенберг В. Шаги за горизонт. - М., 1987.

[3] Корнев С. Столкновение пустот // Новое литературное обозрение. 1997. - №28.

[4] Маркова Л.А. Теология в эпоху постмодернизма // Вопросы философии. -1999 . - №2.

[5] Ратников B.C. Понятие постмодернистской ситуации и ее эпистемологические особенности // Постмодерн: переоцінка цінностей. Виниця, 2001. 